\title{
Contribution of Plant Litter in Fragments of Dry Tropical Forest in Paraíba
}

\author{
Adão Batista de Araújo ${ }^{1}$, Patrícia Carneiro Souto ${ }^{2}$ Jacob Silva Souto ${ }^{2}$, Fabio Junho Alves da Silva ${ }^{2}$, \\ Francisco de Assis Pereira Leonardo ${ }^{2} \&$ César Henrique Alves Borges ${ }^{1}$ \\ ${ }^{1}$ Federal Rural University of Pernambuco, Recife, Pernambuco, Brazil \\ ${ }^{2}$ Federal University of Campina Grande, Patos, Paraíba, Brazil \\ Correspondence: Adão Batista de Araújo, Federal Rural University of Pernambuco, Recife, Pernambuco, Brazil. \\ E-mail: adao.b@hotmail.com
}

Received: September 2, 2018

Accepted: October 6, $2018 \quad$ Online Published: November 15, 2018

doi:10.5539/jas.v10n12p437

URL: https://doi.org/10.5539/jas.v10n12p437

\begin{abstract}
Deposition of plant litter in the environment represents the entrance into the system, with reflection on soil organic matter content and environmental quality of the site. The objective of this study was to estimate the deposition, accumulation and decomposition of plant litter in preserved Caatinga vegetation, and the interference of climatic variability in the dynamics of these events. This research was developed in the Private Natural Heritage Reserve (RPPN), Tamanduá Farm, in the municipality of Santa Terezinha-PB, in a Caatinga area. Plant litter deposited in 20 twenty $1.0 \mathrm{~m}^{2}$ litterfall traps of $1.0 \mathrm{~m} \times 1.0 \mathrm{~m}$ was collected monthly (June/2014 to July/2015), covering the dry and rainy period of the region. The material was separated into leaves, branches + bark, reproductive material and miscellaneous material. Litter stock accumulated on the forest floor was quantified using a $0.5 \mathrm{~m} \times 0.5 \mathrm{~m}$ metal frame to estimate decomposition rate of litter. We found that that leaves fraction obtained the highest deposition average in July 2014 with $395.80 \mathrm{~kg} \mathrm{ha}^{-1}$ and the lowest in February $/ 2015$ with $9.5 \mathrm{~kg} \mathrm{ha}^{-1}$. We concluded that that litter production obtained during the evaluation period was $2.2 \mathrm{mg} \mathrm{ha}^{-1}$, being the highest contribution of litter at the end of the rainy season of the region.
\end{abstract}

Keywords: dry forests, plant litter decomposition, climate variables

\section{Introduction}

Plant litter, a biomass deposited under forested soils, corresponds to the superficial layer composed of leaves, branches, reproductive organs and miscellaneous that are in many stages of decomposition. This material protects the soil against high temperatures, stores large amounts of seeds and shelters an abundant diversity of microorganisms that act directly in processes of decomposition and incorporation of organic material, supplying nutrients to the soil (Souza et al., 2016).

Litterfall production and return of nutrients to forest ecosystems are the most important route of nutrients biogeochemical cycle. This cycle, together with the biochemical one, allows trees to synthesize organic matter through photosynthesis, recycling nutrients which plays a major role in weathered soils where plant biomass becomes the main nutrient reservoir (Schumacher et al., 2013; Gomes et al., 2010).

According to Holanda et al. (2017), the multiple positive functions that plant litter provides for the ecological environment are perceptible in the dynamics of the biogeochemical cycling for different forest ecosystems, that provides improvement in chemical and physical attributes of the soil. However, it is believed that among several forest typologies, there are intrinsic abiotic factors influencing the cycling process, configured through different behaviors of vegetable waste and nutrients.

In areas of Caatinga in the Brazilian Northeast, little is known about deposition and accumulation rates of native forest species. The litter that falls from the trees in this ecosystem protects the soil in the dry season when temperatures are higher, but as soon as the first rains arrive, it is degraded by decomposing microorganisms, and there is no large accumulation of organic material on the surface (Souto, 2006).

In the rainy season, litter decomposition rate in Caatinga area increases in the first six months of exposure and this is because in this period the litter presents a higher concentration of components that are easily leached such 
as extractives and simpler substances such as sugars, which are easily metabolized by microorganisms that act intensely in the process (Souto et al., 2013).

Thus, plant litter deposition process, including annual fall rates of deciduous material and the decomposition process of this material, should be extensively studied, especially in semi-arid conditions where there is a high occurrence of soils with low levels of nutrients due to a key factor in the maintenance of ecosystems (Silva et al., 2015).

In view of the above, the present work aimed to estimate variation in deposition, accumulation and decomposition of plant litter in a preserved Caatinga vegetation in Paraíba semiarid.

\section{Method}

The study was developed in the Private Natural Heritage Reserve (RPPN), belonging to the Tamanduá Farm $\left(7^{\circ} 00^{\prime} 00^{\prime \prime} \mathrm{S}\right.$ and $\left.37^{\circ} 23^{\prime} 00^{\prime \prime} \mathrm{W}\right)$, located in the municipality of Santa Terezinha-PB, with an average altitude of 300 meters (Figure 1).

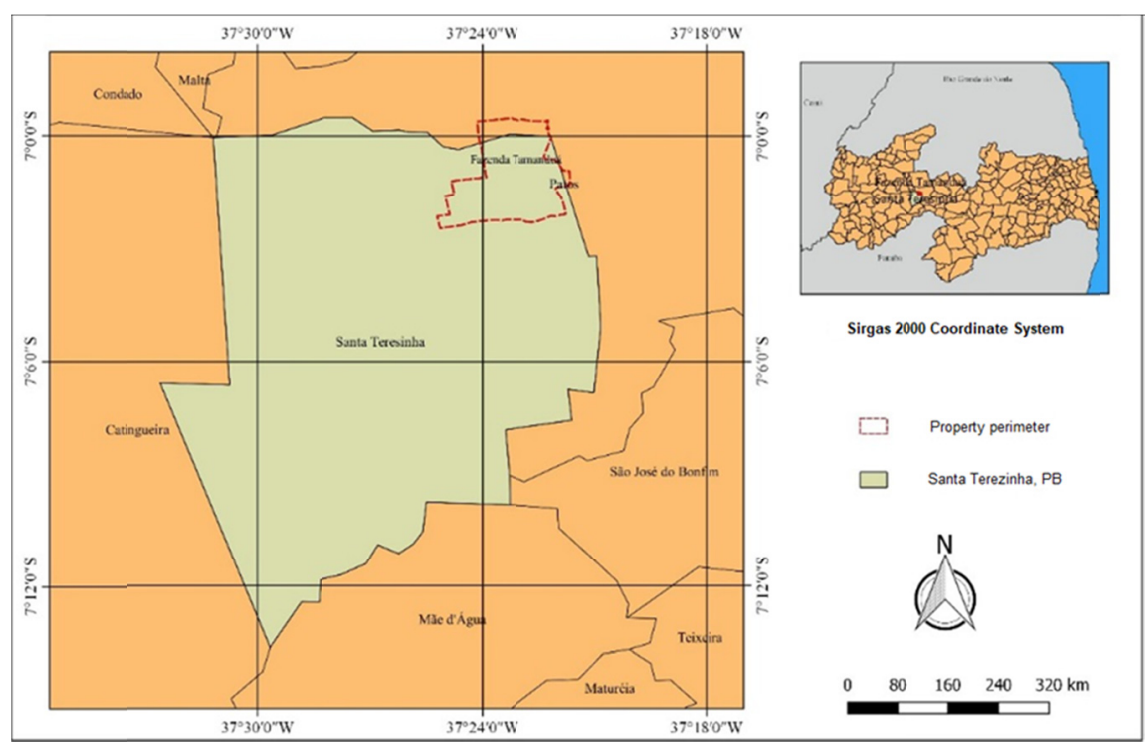

Figure 1. Map of Paraíba state, highlighting the RPPN of Tamanduá Farm, in the municipality of Santa Terezinha

The climate of the region, according to the classification of Köppen (Alvares et al., 2013) is BSh type, semi-arid, marked by a dry season and a rainy season. Average annual rainfall is about $600 \mathrm{~mm}$, according to Brasil (1978). Soils are classified as Luvisols (Barroso, 2017).

Twenty litterfall traps were installed in a systematic way, 30 meters from each other, in the year 2003. Collection boxes had dimensions of $1.0 \mathrm{~m}^{2}$, made with iron bars and nylon mesh of $1.0 \mathrm{~mm} \times 1.0 \mathrm{~mm}$ which were installed $10.0 \mathrm{~cm}$ above the soil surface. Monthly, during the period of one year (July/2014 to June/2015), all material present in the boxes was collected. In the Laboratory of Mineral Nutrition of Plants (LabNut) of the Federal University of Campina Grande, in Patos-PB, fractions were divided in leaves, branches + bark, reproductive structures (flowers + fruits + seeds) and miscellaneous (material of $2.0 \mathrm{~mm}$ in diameter, difficult to identify, and feces). After separation, fractions were packed in paper bags and properly identified, and taken to the oven at $65^{\circ}$ $\mathrm{C}$ until reaching a constant mass.

To evaluate the decomposition rate of the litter, litter accumulated at the soil surface was measured monthly using a metal frame with dimensions of $0.5 \mathrm{~m} \times 0.5 \mathrm{~m}$, which was cast three times in each transect randomly. Accumulated litter collections on the forest floor included the dry period and the rainy season, thus detecting possible seasonal variations in these compartments.

All the litter circumscribed in the frame was carefully collected, so as not to collect the soil, and packed in plastic bags. In the laboratory, each sample was cleaned for removal of stones and/or soil adhered to the material. After this procedure, the residues were packed in properly labeled paper bags, placed in an oven at $65{ }^{\circ} \mathrm{C}$ to dry until constant weight, and then weighed in a precision scale. 
To reduce the coefficient of variation between weights of fractions deposited in the twenty collectors installed, at the end of the experiment the deposition values were added to each four collectors and, afterwards, the average was calculated resulting in five monthly repetitions. Thus, the experimental design used to analyze litter deposition was randomized blocks with treatments in factorial arrangement $12 \times 2$ (months $\times$ periods), with five replications.

\section{Results}

Plant litter, due to its varied composition of plant and organic material, suffers a great influence of climatic aspects of the region, factors that are decisive for the regulation of the quantity of vegetal material contributed and/or accumulated. Climatic data were tabulated in monthly averages, except rainfall, for an easy correlation between monthly means of plant litter and thus to explain the results obtained in the experimental period. Distribution of temperature, wind speed, relative humidity and insolation data for the period when evaluations were carried out is shown below (Table 1).

Table 1. Climatic variables registered in RPPN Tamanduá Farm, in Santa Terezinha, PB

\begin{tabular}{lllll}
\hline \multirow{2}{*}{ Months } & \multicolumn{3}{c}{ Variables } \\
\cline { 2 - 5 } & Temperature $\left({ }^{\circ} \mathrm{C}\right)$ & Wind speed $\left(\mathrm{m} \mathrm{s}^{-1}\right)$ & Relative humidity $(\%)$ & Insolation (h) \\
\hline Jul/14 & 26.17 & 3.43 & 61.89 & 240.6 \\
Ago/14 & 26.86 & 3.82 & 49.25 & 299.3 \\
Set/14 & 27.53 & 4.41 & 52.70 & 268.4 \\
Out/14 & 27.91 & 4.40 & 50.59 & 287.2 \\
Nov/14 & 28.55 & 3.72 & 49.60 & 277.6 \\
Dez/14 & 28.58 & 3.63 & 50.70 & 286.4 \\
Jan/15 & 29.02 & 3.76 & 49.04 & 299.1 \\
Fev/15 & 27.91 & 58.83 & 220.8 \\
Mar/15 & 27.94 & 2.57 & 62.25 & 264.1 \\
Abr/15 & 2.07 & 67.30 & 283.0 \\
Mai/15 & 27.34 & 3.35 & 54.39 & 286.6 \\
Jun/15 & 28.59 & 4.30 & 61.13 & 212.9 \\
\hline
\end{tabular}

Source: Data obtained at Fazenda Tamanduá.

Regarding winds, the highest speeds recorded were in September and October/2014, with 4.41 and $4.40 \mathrm{~m} \mathrm{~s}^{-1}$. This promotes faster dryness of branches that are already devoid of leaves, in most species. The lowest percentages of relative humidity were recorded in August-November/2014 and January/2015, all below 50\%. This favors water loss from the residues that have already been deposited in the soil to the atmosphere.

Regarding soil water content (Table 2), the highest average was recorded in January/2015 with 11.53\%, and the lowest average in October/2014 with $0.84 \%$. This higher water content in the soil in January/2015 may be due to rainfall recorded in the previous months (November and December/2014), with $90.6 \mathrm{~mm}$, which contributed to soil water maintenance. 
Table 2. Monthly average values and variation coefficient of soil water content in RPPN Tamanduá Farm, Santa Terezinha, PB

\begin{tabular}{ll}
\hline Months & Humidity $(\%)$ \\
\hline Jul/14 & $2.50 \mathrm{~d} \mathrm{e}$ \\
Ago/14 & $1.06 \mathrm{~d} \mathrm{e}$ \\
$\mathrm{Set} / 14$ & $0.98 \mathrm{~d} \mathrm{e}$ \\
$\mathrm{Out} / 14$ & $0.84 \mathrm{e}$ \\
$\mathrm{Nov} / 14$ & $1.75 \mathrm{~d} \mathrm{e}$ \\
$\mathrm{Dez} / 14$ & $2.81 \mathrm{~d}$ \\
$\mathrm{Jan} / 15$ & $11.53 \mathrm{a}$ \\
$\mathrm{Fev} / 15$ & $7.30 \mathrm{~b}$ \\
$\mathrm{Mar} / 15$ & $8.67 \mathrm{~b}$ \\
$\mathrm{Abr} / 15$ & $4.99 \mathrm{c}$ \\
$\mathrm{Mai} / 15$ & $2.58 \mathrm{~d} \mathrm{e}$ \\
$\mathrm{Jun} / 15$ & $2.17 \mathrm{~d} \mathrm{e}$ \\
$\mathrm{CV}(\%)$ & 26.38 \\
$\mathrm{DMS}$ & 1.87 \\
\hline
\end{tabular}

During the evaluation period, total plant litter production was $2.225 .04 \mathrm{~kg}$ ha year ${ }^{-1}$ (Table 3), corresponding to an annual deposition of $2.22 \mathrm{mg} \mathrm{ha}^{-1}$, with emphasis on the contribution of the leaf fraction with $62.27 \%$ of the total, and the other fractions with $22.81 \%$ (branches + barks), $14.11 \%$ (reproductive material) and $0.81 \%$ (miscellaneous).

Table 3. Total yield $\left(\mathrm{kg} \mathrm{ha}^{-1}\right)$ and percentage $(\%)$ of contribution of each fraction in the formation of plant litter in RPPN Tamanduá Farm, Santa Terezinha, PB

\begin{tabular}{lll}
\hline Months & Humidity $\left(\mathrm{kg} \mathrm{ha}^{-1}\right)$ & Percentage (\%) \\
\hline Leaf & 1385.56 & 62.27 \\
Branches + barks & 507.63 & 22.81 \\
Reproductive material & 313.86 & 14.11 \\
Miscellaneous & 17.99 & 0.81 \\
Total & 2.225 .04 & 100 \\
\hline
\end{tabular}

In the studied area, cumulative rainfall from July/2014 to June/015 was $454.1 \mathrm{~mm}$, with February being 89.80 $\mathrm{mm}$ and March with $163.6 \mathrm{~mm}$. Data confirmed the uneven distribution of precipitation from one year to the other. However, the month of March configures the one with the highest occurrence of rainfall for the region.

Litter production presented a significant variation during months, mainly in the leaves fraction, having precipitation as a key factor that, when reducing indexes, favored the intensity of leaf fall with a consequent increase in contribution. It is important to emphasize that most of the species in the studied area present deciduous as a survival mechanism in the semi-arid region to the adverse conditions to which they are regularly submitted, varying only the intensity of events over the years.

Analyzing the contribution of each fraction that compose plant litter, there was a difference in leaf deposition between evaluated months, with the highest average recorded in July/2014 with $395.80 \mathrm{~kg} \mathrm{ha}^{-1}$ and the lowest average in February/2015 with $9.5 \mathrm{~kg} \mathrm{ha}^{-1}$ (Figure 2). 


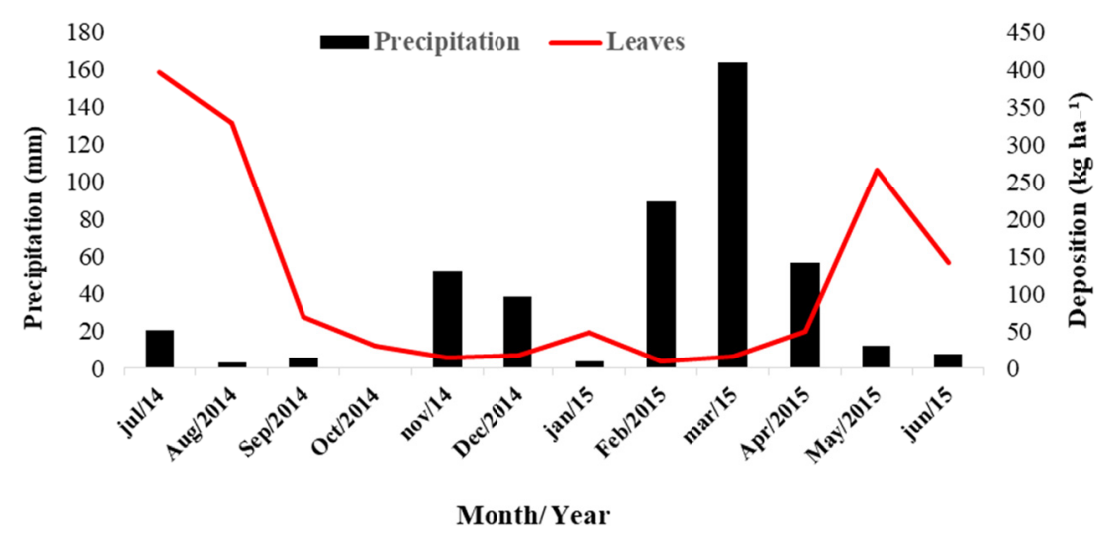

Figure 2. Average monthly contribution of leaves fraction and rainfall in RPPN Tamanduá Farm, Santa Terezinha, PB

In relation to the branches + bark fraction, it can be seen in Figure 3 that in July/2014 the highest deposition occurred with $102.09 \mathrm{~kg} \mathrm{ha}^{-1}$, and the lowest average in February $/ 2015$ with $16.32 \mathrm{~kg} \mathrm{ha}^{-1}$. The highest average in July/2014 may have been influenced by the strongest winds in the area whose velocity was above 3.4 since that month, and intensified until January/2015 (Table 1). Rainfall reduction, associated with loss of foliage by most species, exposes the woody part of the canopy to mechanical action of wind, promoting the breaking of thin and/or dry branches as well as detachment of bark.

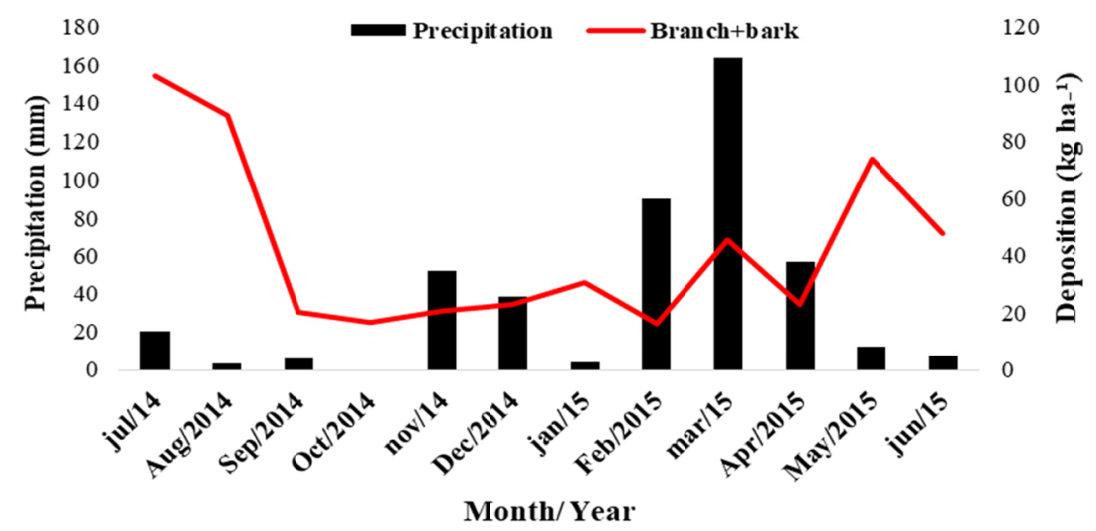

Figure 3. Average monthly contribution of the branches + bark fraction and rainfall in RPPN Tamanduá Farm, Santa Terezinha, PB

During the experimental period, production of reproductive material fraction was $313.86 \mathrm{~kg} \mathrm{ha}^{-1}$ and there was a difference between monthly averages (Figure 4), with the highest average in the month of August/2014 with $116.54 \mathrm{~kg} \mathrm{ha}^{-1}$ which corresponded to $37.13 \%$ of the total contributed during the evaluation period, and the lowest was recorded in May/2015 with $1.2 \mathrm{ha}^{-1}$. Production peak occurred in August $/ 2014$ with $116.54 \mathrm{~kg} \mathrm{ha}^{-1}$, which corresponds to $37.13 \%$ of the total. It is observed that the reproductive material fraction is influenced by precipitation, that is, the highest peak occurred at the end of the rainy season (August 2014) and another peak at the end of the dry period when the first rain in the region begin to occur, indicating that in preserved Caatinga fragments the species diversity allows variability in phenology, thus providing the equilibrium of this ecosystem, which is often subject to low water availability.Provide dates defining the periods of recruitment and follow-up and the pnmary sources of the potential subjects, where appropriate. If these dates differ by group, provide the values for each group. 


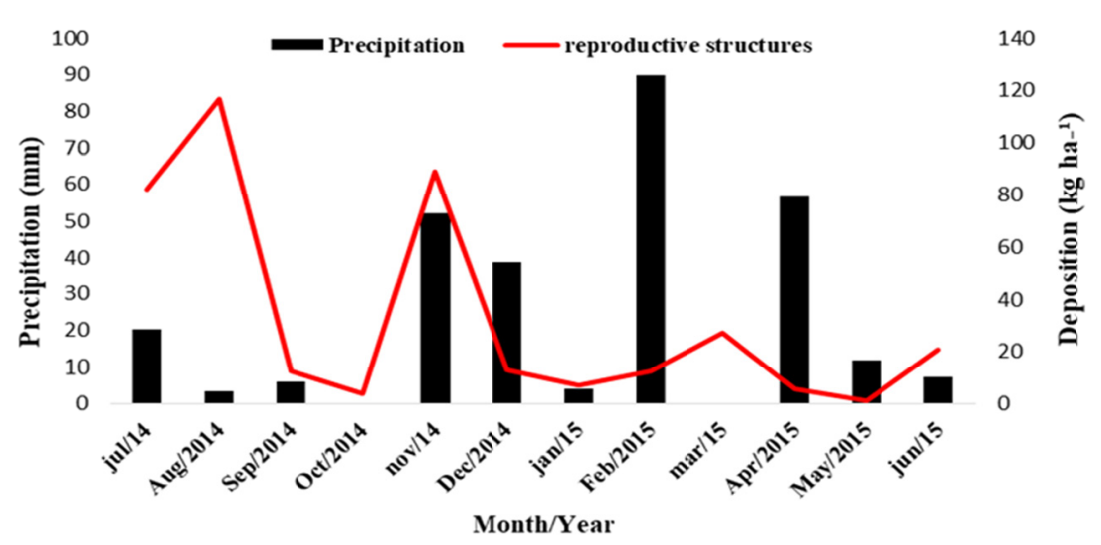

Figure 4. Average monthly contribution of the reproductive structures fraction and rainfall in RPPN Tamanduá Farm, Santa Terezinha, PB

Figure 5 shows that from July/2014 to June/2015 deposition of miscellaneous fraction was always smaller, when compared to deposition of reproductive material fraction.

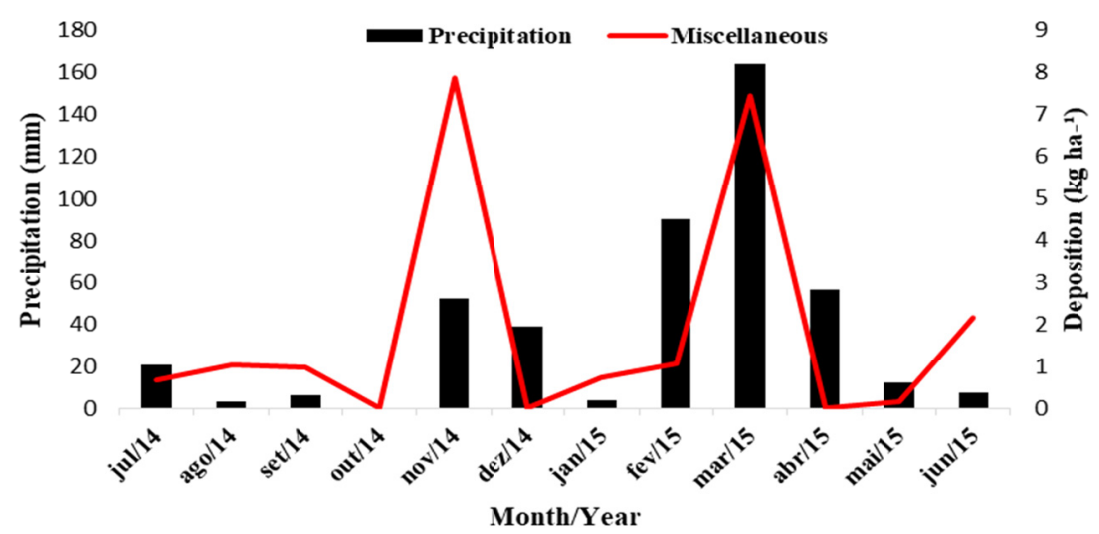

Figure 5. Average monthly contribution of the miscellaneous fraction and rainfall in RPPN Tamanduá Farm, Santa Terezinha, PB

The peak of production of miscellaneous fraction was in the month of November $/ 2014$ with $7.86 \mathrm{~kg} \mathrm{ha}{ }^{-1}$ or $43.69 \%$ of the total contributed. It is also verified that, even in the maximum production period, the miscellaneous fraction obtained the lowest average. The miscellaneous fraction presents the greatest difficulty in its identification because besides containing the tiny vegetal residues it has insect parts, excreta and other materials of difficult recognition.

\section{Discussion}

In Caatinga, leaves fractionation seems to be linked to two highly related factors, which are the beginning of dry period in the area, with a reduction of moisture content in the soil, and the deciduous character of the species, with consequent and immediate abscission of leaves to reduce water loss through perspiration. Thus, as some Caatinga species retain part of their leaves during the year, even with water deficiency, it is probable that the deposition peak of deciduous foliar biomass at the beginning of the dry period is a result of the loss of deciduous leaves (Santana \& Souto, 2011).

Rowland et al. (2018), studying leaf litter dynamics, found that strong changes in foliage seasonality and litterfall resulted in seasonal correlations with weather factors (air temperature, radiation, air humidity and precipitation) compared to native forest.

For total plant litter production, Holanda et al. (2017) report higher values for Caatinga area than the present study, with a yield of $3,758.67 \mathrm{~kg} \mathrm{ha}^{-1}$, with the leaves fraction also being highlighted. According to Costa et al. 
(2010), plant litter production in Caatinga biome ranges from 1,500 to $3,500 \mathrm{~kg} \mathrm{ha}^{-1}$, and these values are determined by common morphological and physiological characteristics of plants that make up the biome.

Regarding the leaves fraction, the percentage obtained in this study was similar to that reported by Costa et al. (2010) in a Caatinga area in the municipality of Açú-RN, with a contribution of $65 \%$ of this fraction forming the litter. The authors point out that leaves are fundamental in processes of photosynthesis and transpiration of plants, that demand a great amount of water. Thus, during the dry season in Caatinga, plants lose their leaves as an adaptive mechanism to water stress to which they are submitted, hence the great contribution of leaf litter produced.

Bernaschini et al. (2016) in their study, questioned the fact that the litter decomposition had an influence on the size of the forest and the decomposition of invertebrates in the semiarid region of Argentina. Finally, they concluded that the first studies of the decomposition in these areas in the dry period did not succeed, that is, the size of the fragment did not affect the decomposition.

Garbage decomposition is a fundamental process in the functioning of forest ecosystems as it facilitates the recycling of nutrients and chemical elements, and regulates forest restoration and productivity (Cleveland et al., 2011). Lin et al. (2017) studying the decomposition of litter in subtropical forests, found that there was no high decomposition of dominant species. However, they found positive effects for certain species in the region.

In a work evaluating contribution and decomposition of plant litter in a Caatinga area in the South of Piauí, Lima et al. (2015) observed a significant correlation at the $1 \%$ level between litter deposition and rainfall during the studied period, proving that precipitation has a significant influence on deposition of deciduous material of this area. It is also worth noting that in the months of June to September the largest deposition of litter occurred, so that this is the period of lower rainfall in which forest species lose their leaves to reduce evapotranspiration.

Costa et al. (2015) confirm that factors such as precipitation and wind are determinant for greater deposition of the branches fraction. According to Souto (2006), comparison of data related to branches fraction is difficult because, unlike leaves fraction that are sampled by similar methods in the most varied ecosystems, there is no standardization regarding dimensions of the branches. For Holland et al., (2017), the branches fraction was the third component with the highest deposition rate $\left(352.29 \mathrm{~kg} \mathrm{ha}^{-1}\right)$ representing $9.3 \%$ of the total.

Studies developed in Caatinga by Silva et al. (2015) had a contribution of the miscellaneous fraction of $61.96 \mathrm{~kg}$ $\mathrm{ha}^{-1}$, with the highest contribution of this fraction in June/2014 with $19.1 \mathrm{~kg} \mathrm{ha}^{-1}$, which are higher than the values reported in the present study.

\section{Conclusion}

Plant litter production obtained in the evaluated period (July/2014 to June/2015) was $2.2 \mathrm{mg} \mathrm{ha}^{-1}$ and it fits the average production for the Caatinga biome;

The highest contribution of plant litter occurs at the end of the rainy season in the region, with leaf fraction being the most expressive in the composition of the litter, a fact attributed to rainfall irregularity and deciduous tree which is the defense mechanisms of most of Caatinga tree species;

Decomposition of plant litter is slow, which provides greater soil protection against erosive process and favors the reduction of water evaporation. On the other hand, the release of nutrients via litter decomposition is also slower, thus indicating that the maintenance of this organic blanket in Caatinga is of fundamental importance for its sustainability and equilibrium over time, and practices such as fires that rapidly destroy this layer should be vigorously combated.

\section{References}

Alvares, C. A., Stape, J. L., Sentelhas, P. C., Gonçalves, J. L. M., \& Sparovek, G. (2014). Köppen's climate classification map for Brazil. Meteorologische Zeitschrift, 22(6), 711-728. https://doi.org/10.1127/0941-29 48/2013/0507

Brazil/MA. (1978). Basic studies for the agricultural survey: Agricultural aptitude of the lands of Paraiba (Vol. 3, p. 23). Brasília: BINAGRI.

Bernaschini, M. L., Moreno M. L., Pérez-Harguindeguy N. P., \& Valladares, G. (2016). Is litter decomposition influenced by forest size and invertebrate detritivores during the dry season in semiarid Chaco Serrano? Journal of Arid Environments, 127, 154-159. https://doi.org/10.1016/j.jaridenv.2015.11.009 
Cleveland, C. C., Townsend, A. R., Taylor, P., Alvarez-Clare, S., Bustamante, M. M., Chuyong, G., ... Wieder, W. R. (2011). Relationships among net primary productivity, nutrients and climate in tropical rain forest: a pan-tropical analysis. Ecol. Lett., 14, 939-947. https://doi.org/10.1111/j.1461-0248.2011.01658.x

Costa, C. C. A., Camacho, R. G. V., Macedo, I. D. de, \& Silvaet, P. C. M. da. (2010). Comparative analysis of litter production in shrub-trees fragments in a caatinga area of FLONA Açu-RN. Revista Árvore, 34(2), 259-265. https://doi.org/10.1590/S0100-67622010000200008

Costa, J. T. F., Silva, L. S., Alves, A. R., Holanda, A. C., Leite, E. M., \& Nunes, A. K. A. (2015). Evaluation of litter in the riparian area of the river basin south of Piauí Gurguéia. Revista Verde de Agroecologia e Desenvolvimento Sustentável, 10(1), 13-19. https://doi.org/10.18378/rvads.v10i1.3201

Gomes, J. M., Pereira, M. G., Piña-Rodrigues, F. C. M., Pereira, G. H. A., Gondim, F. R., \& Silva, E. M. R. (2010). Litter fall and nutrient contribution in forest fragments on the Atlantic forest, RJ, Brazil. Revista Brasileira de Ciências Agrárias, 5(3), 383-391. https://doi.org/10.5039/agraria.v5i3a552

Holanda, A. C. D., Feliciano, A. L. P., Freire, F. J., Sousa, F. Q. D., Freire, S. R. D. O., \& Alves, A. R. (2017). Litter production and nutrients in area of caatinga biome. Ciência Florestal, 27(2), 621-633.

Lima, R. P., Fernandes, M. M., Fernandes, M. R. M., \& Matricardi, E. A. T. (2015). Litter Contribution and Decomposition in the Caatinga in Southern Piauí State, Brazil. Revista Floresta e Ambiente, 22(1), 42-49. https://doi.org/10.1590/2179-8087.062013

Lin, H., Zaihua, H., Jiewei, H., Kai, T., Xiuqin, J., Xiangshi, K., Siddiq, A., Zhanlin, B., \& Xinfjun, T. (2017). Effect of $\mathrm{N}$ addition on home-field advantage of litter decomposition in subtropical forests. Forest Ecology and Management, 398, 216-225. https://doi.org/10.1016/j.foreco.2017.05.015

Santana, J. A. S., \& Souto, J. S. (2011). Litterfall in the Caatinga of the semi-arid region of Rio Grande do Norte, Brazil. Idesia, 29(2), 87-94. https://doi.org/10.4067/S0718-34292011000200011

Schumacher, M. V., Brun, E. J., Rodrigues, L. M., \& Santos, E. D. (2003). Nutrient return via litter deposition in a black wattle (Acacia mearnsii de Wild.) stand in rio grande do sul, Brazil. Revista Árvore, 27(6), 791-798. https://doi.org/10.1590/S0100-67622003000600005

Silva, V. N., Souto, L. S., Dutra Filho, J. D. A., Souza, T. M., \& Borges, C. H. A. (2015). Litter deposition in a savanna area preserved in the semiarid region of Paraíba, Brazil. Revista Verde de Agroecologia e Desenvolvimento Sustentável, 10(2), 21-25. https://doi.org/10.18378/rvads.v10i2.3409

Souto, P. C. (2006). Accumulation and decomposition of litter and distribution of edaphic organisms in caatinga area in Paraiba, Brazil (150 f., Thesis (PhD in Agronomy), Federal University of Paraiba, Areia, PB).

Souto, P. C., Souto, J. S., Santos, R. V., Bakke, I. A., Sales, F. C. V., \& Souza, B. V. (2013). Rate of litter decomposition and microbial activity in an area of caatinga. Cerne, 19(4), 559-565. https://doi.org/10.1590/ S0104-77602013000400005

Souza, B. V., Souto, J. S., Souto, P. C., Sales, F. C. V., \& Guerrini, I. A. (2016). Assessment of the seasonality of litterfall in conservation area of Caatinga in Paraiba, Brasil. Agropecuária Científica do Semiárido, 12(3), 325-331.

Rowland, L., Costa, A. C. L., Oliveira, A. A. R., Almeida, S. S., Ferreira, L. V., Malhi, Y., .. Meir, P. (2018). Shock and stabilisation following long-term drought in tropical forest from 15 years of litterfall dynamics. Journal of Ecology, 106, 1673-1682. https://doi.org/10.1111/1365-2745.12931

\section{Copyrights}

Copyright for this article is retained by the author(s), with first publication rights granted to the journal.

This is an open-access article distributed under the terms and conditions of the Creative Commons Attribution license (http://creativecommons.org/licenses/by/4.0/). 